\title{
Öğretmenlerin Örgütsel Vatandaşlık Davranışlarının Yordayıcısı Olarak Örgütsel Sosyalleşme ${ }^{2}$
}

\author{
Çayhan YILDIRIM \\ Sabahattin Zaim Üniversitesi Eğitim Fakültesi, caycay75@hotmail.com \\ Sultan Bilge KESKINKILIÇ KARA \\ Sabahattin Zaim Üniversitesi Eğitim Fakültesi, bilge.kara@izu.edu.tr
}

DOI: $10.21666 /$ muefd.396645

Özet

Bu araştırmanın amacl ögretmenlerin örgütsel sosyalleşme düzeylerinin örgütsel vatandaşllk davranışlarının yordayıcısı olup olmadığını belirlemektir. Yordayıcı ilişkisel tarama türünde desenlenmiş olan araştırmanın örneklemini İstanbul ili Esenyurt İlçesinde bulunan 14 lisede görev yapan 480 ögretmen oluşturmaktadır. Veri toplama aracı olarak Örgütsel Sosyalleşme Ölçeği ve Örgütsel Vatandaşlık Davranışı Ölçeği kullanılmıştır. Araştırmadan elde edilen sonuçlara göre lise ögretmenlerinin örgütsel sosyalleşme düzeyleri genel puan ortalamaları çok katılıyorum düzeyinde iken en yüksek algıladıkları boyut amaç ve değer boyutu tamamen katıllyorum düzeyinde, en düșük alglladıkları boyut örgüt dili ve tarihi boyutu katılıyorum düzeyindedir. Öğretmenlerinin örgütsel vatandaşlık düzeyleri genel puan ortalamaları tamamen katılıyorum düzeyinde iken en yüksek algıladıkları centilmenlik boyutunda tamamen katılıyorum düzeyinde, en düşük algıladıkları sivil erdem boyutu çok katıllyorum düzeyindedir. Öğretmenlerin örgütsel sosyalleşme düzeyleri ölçeğinin mesleki yeterlik, kişilerarası ilişkiler, örgüt tarihi ve dili, örgüt politikası, örgütsel amaç ve değerlere uyum düzeyi ile örgütsel vatandaşlık düzeyleri ölçeğinin centilmenlik, vicdanlılık, sivil erdem ve yardımlaşma boyutları arasında orta düzeyde pozitif ilişki olduğu sonucuna ulaşılmıştır. Araştırmada, ayrıca, öğretmenlerin örgütsel sosyalleşme düzeylerinin örgütsel vatandaşlık davranışlarını yordadı̆̆ sonucuna ulaşılmıştır

Anahtar Kelimeler: Örgütsel sosyalleşme, örgütsel vatandaşlık.

\section{Organizational Socialization as a Predictor of Organizational Citizenship Behaviors of Teachers}

\begin{abstract}
Summary of this research is to determine whether the level of organizational socialization of teachers is the predictor of their organizational citizenship behaviors. The sample of the research that is in the form of predictive relational screening is composed of 480 teachers working in 14 high schools located in the metropolitan Istanbul's district of Esenyurt. The "Organizational Socialization Scale" and the "Organizational Citizenship Behavior Scale" were used as tools. According to the results obtained reseain the research, the organizational socialization levels of the high school teachers are at the level of agreement on the general scores, while the highest agree is being on shared values and the lowest being language and the historical dimension. The level of organizational citizenship of the teachers is at the level of agreeing fully with the overall score, while at the level of fully agreeing with the courtesy and cooperative dimensions that they perceive the most, the level of civil virtue that they have the lowest level is very agreeable. It was concluded that the level of organizational socialization levels of teachers was moderately positive between gender competences, interpersonal relations, organizational history and language, organizational politics, organizational goals and values, organizational citizenship levels, gender, conscience, civic virtue and helpfulness dimensions. The survey also found that organizational socialization levels of teachers has a good predictions on their organizational citizenship behaviors
\end{abstract}

Key Words: Organizational socialization, organizational citizenship

Örgütsel vatandaşlık, işgörenlerin, kendilerine resmi olarak bildirilmiş görev tanımlarının dışında tamamen gönüllü olarak ve herhangi bir ödül beklemeden, örgüt ve diğer işgörenler için yaptıkları fazladan davranışlardır (Organ, 1997). Bir başka tanıma göre örgütsel vatandaşlık davranışı, örgüt çalışanlarının kendilerinden beklenen rollerden ve görevlerden ayrı olarak, örgütün rekabet gücünü ve

\footnotetext{
${ }^{2}$ Bu makale Çayhan Yıldırım'ın İstanbul Sabahattin Zaim Üniversitesi Sosyal Bilimler Enstitüsü için hazırlamış olduğu Yüksek Lisans Tezinden türetilmiştir
} 
bireylerin performansını etkileyen gönüllü davranışı olarak tanımlanmıştır (Podsakoff, MacKenzie, Paine, ve Bachrach, 2000). Bu tür davranışlar, daha çok bireysel bir seçimdir ve yapılması durumunda çalışana doğrudan herhangi bir ödül verilmesinin beklenmediği, yapılmaması durumunda da herhangi bir ceza gerektirmeyen davranışlardır. $\mathrm{Bu}$ davranışların genel özelliği, yazılı olarak ifade edilmemelerinin ve bir zorunluluk olmamalarına rağmen örgüte dolaylı olarak katkı sağlamalarıdır. Yani bireysel seçime bağlı olarak gerçekleşen bir davranıştır. Günlük yapılan işler içerisinde oluşan işbirliği, öneriler, yardımlaşmalar, destekler vb. çok sayıda eylem, örgütsel vatandaşlı̆̆a örnek olarak gösterilebilir (Smith, Organ ve Near, 1983).

Örgütsel vatandaşlık davranışı hem bireysel hem de örgütsel boyutta sağladığı yararlar açısından oldukça önemlidir. Örgütsel vatandaşlık davranışı sergileyen çalışanlar, çalıştığı örgütle bütünleşerek, örgütün amaçlarını kendi amaçlarının önünde tutarlar ve bu sayede örgüt, en zor şartların bile üstesinden gelebilir (Bozkurt, 2007). Bireylerin sergiledikleri örgütsel vatandaşlık davranışları bilinçli ya da bilinçsiz olarak örgütün performansını olumlu olarak etkileme gücüne sahiptir.

Organ (1988) örgütsel vatandaşlık davranışını beş farklı boyutta incelemiştir. Bunlar, özgecilik (Altruism), vicdanlllik (Constientiousness), centilmenlik (Sportmanship), nezaket (Courtesy) ve sivil erdemdir (Civic Virtue). Özgecilik kavramı, genel olarak örgüt içerisinde bireylerin diğer çalışanlara karşı gönüllü ve karşı1ıksız olarak yardımcı olmaları olarak tanımlanmaktadır. Hastalanan bir çalışanın görevlerinin diğer iş arkadaşı tarafindan tamamlanması, örgüte yeni katılan işgörenlere uyum konusunda yardımcı olunması, diğerleri tarafından gereksinim duyulan bir bilginin paylaşımı özgeci davranışa örnek olarak verilebilir. Örgüt içerisinde çalışanların bu şekilde iyi niyetli davranışları, işlerin daha düzenli işlemesini sağlamaya yardımcı olmaktadır (Demirci, Erbaş ve Giderler, 2009). Bu tip davranışlar, aynı zamanda, örgüt içerisinde çatışmaların büyümesini önleyecek niteliktedir (Podsakoff ve Mackenzie, 1997). Örgütlerde özgecilik davranışının artması örgüt içerisinde işlevsel olmayan ve gerginlik yaratacak davranışların azalmasına ve bu sayede örgütsel etkinliğin yükselmesine neden olacaktır (Titrek, Bayrakçı ve Zafer, 2009).

Vicdanlılık, örgütteki çalışanların bazı rol davranışlarını kendilerinden beklenenin üzerinde sergilemesidir (Organ, 1990). Bu kapsamda işe devam, işe zamanında başlama ve iş yerinden zamanında çıkma, görevinin ve örgütün gerektirdiği kurallara uyma davranışları örnek olarak gösterilmektedir. Örneğin, çalışanın işine düzenli olarak devam etme kuralı iş sözleşmesinde yer alan bir yükümlülük iken, çoğu zaman gönüllülüğe dayandığı noktalar da bulunmaktadır. S1klıkla olmamak kaydıyla çalışanın çok önemli bir rahatsızlığı olmamasına rağmen işe gelmemesi, özel hayatını bahane ederek devamsızlık yapması çoğu zaman yöneticiler tarafından kabul edilebilir davranışlardır. Çalışanın bu kabule rağmen, işe devam konusunda kendisinden beklenenin üzerinde bir çaba sergilemesi vicdanll11k boyutunun gereklerini yerine getirmesi olarak sayılmaktadır. Çalışanın fazla mesai ücreti almamasına rağmen işini bitirmek için mesaiye kalması, örgütün yararına olan toplantılara katılması, su-elektrik gibi örgüt kaynaklarını ve araç gereçleri israfa kaçmadan kullanması da vicdanlılık boyutuna örnek gösterilebilir (Podsakoff, MacKenzie ve Hui, 1993).

Nezaket, örgütte, çalışanların işlerini etkileyebilecek sorunların önüne geçebilmek amacıyla onlara yardımcı olabilecek davranışları ifade etmektedir. Bu boyutta temel nokta, çalışanların işlerini yaparken onları etkileyecek davranışlar sergilemeden önce dikkatli ve düşünceli davranmaları gerektiği konusunda yardımcı olmaktır (Sezgin, 2005). Nezaket boyutundaki davranışların ortak özelliği, herhangi bir sorun ortaya çıkmadan örgüt üyelerini uyarmak için sergilenen davranışlar olmasıdır. Örgüt içerisinde verilecek kararlar öncesinde diğer çalışanların görüş ve önerilerinin alınması, örgüt içindeki, diğer çalışanların sahip oldukları haklara saygı göstermek, genel konularda hatırlatma ve danışma davranışları sergilemek nezaket davranışına örnek olarak verilebilir (Gürbüz, 2006).

Sivil erdem, örgüt çıkarlarını üst seviyede gözeterek gerek mesleki gerekse sosyal anlamda örgütü destekleyerek, örgütte gönüllü olarak bulunmayı ifade etmektedir (Sezgin, 2005). Sivil erdem, bir bütün olarak ve en üst düzeyde örgütsel ilgiyi ve örgütsel yaşama etkin ve gönüllü olarak katılımı ifade eder (Terzi, 2011). Organ'a göre, örgüt içerisindeki iyi bir örgüt vatandaş1 çalıştığ 1 örgütte yalnızca sorgusuzca uyum sağlamaya çalışan bir kişi olmamalı, örgütle ilgili tüm konularda düşünemeye çalışmalı ve ürettiği bu yeni düşünceleri paylaşmaktan kaçınmamalıdır (Karaman ve Aylan, 2012).

Örgütsel vatandaşlık davranışının centilmenlik boyutu, işgörenlerin örgüt içerisinde yaşanan ya da karşılaşılan sorunları şikayet etmeden aşmaya çalışarak, işe ve örgüt kültürüne ilişkin olumlu bir bakış açısına sahip bir biçimde, istekli çalışmaları anlamına gelir. Centilmenlik davranışı, örgüt içinde bireyler 
arasında gerginlik oluşturabilecek her türlü davranıştan uzak durmayı gerektirmektedir (Özdevecioğlu, 2003). Centilmenlik, örgütle ilgili olumsuz konularda suçlama yapmamak, şikayet etmemek, olumsuzlukları hoşgörmek, yaptığı işi başkalarını rahatsız etmeden yerine getirmek gibi olumlu davranışları kapsar (Alizadeh vd., 2012). Centilmenlik davranışının sergilendiği örgütlerde bireyler ve gruplar arası çatışmaların çözümünde yöneticiye daha az başvurulacak ve etkililiğin artmasına katkı sağlayacaktır (Ay, 2007). Böyle bir tutum, işgörenler arasında sorunların ortaya çıkmasını önleyecek, yapıcı davranışları cesaretlendirecek, bireysel olgunluğu artıracak, örgüt içinde hoşgörü kültürünün gelişmesine katkı sağlayacak niteliktedir.

Örgütsel vatandaşlık davranışı son yıllarda özellikle insan kaynakları yönetimi ve örgütsel davranış alanlarında yoğun bir şekilde incelenmektedir. Bunun nedeni örgütsel vatandaşlık davranışının örgütün verimliliğine, çalışanların edimlerine, örgüte bağl1lığa ve güdülenmeye etki ettiğinin düşünülmesidir (Gürel, 2012).

\section{Örgütsel Sosyalleşme}

Sosyalleşme kavramını, sosyal bilimler alanyazınına sokan ilk düşünür E. Durkheim'dır (Ergün, 1992). Sosyalleşme bireyin, toplum ve çeşitli grupların bir üyesi haline getirilen değer, tutum ve davranışlarını, kurumsallaşmış normlara uygun olarak sergilenmesine olanak veren bir kültürlenme sürecidir (Güney, 2000). Etzioni (1975)'ye göre sosyalleşme, bireyin inanç, norm, değer ve görüşlerini örgütle aynı çizgiye getirme sürecidir. Bu süreç bireyin yeni bir örgüte veya toplumsal birime üye olması veya birim içinde statü değişimi halinde yeni becerileri öğrenme ve rol uyumunu sağlamasına yönelik olarak gelişimidir. Toplumsal açıdan sosyalleşme, toplumsal ve kültürel mirasın gelecek nesillere aktarılması ve kişiliğin gelişimi olarak da tanımlanabilir (Özkalp, 2005). Sosyalleşme ile ilgili tanımlarda dikkat çeken özellik, öğrenme sürecinden ve toplumun öğreticiliğinden söz edilmekte olup, insanın bu öğrenme sonucunda kendisini geliştirerek topluma uyumlu hale geldiği ve insanın, doğası gereği sosyal bir varlık olduğu vurgulanmaktadır.

Örgütün bütünlügünü sürdürebilmek açısından değer, norm, ilke, inanç ve işleyiş biçimlerinin işgörenler tarafindan anlaşılmasını içeren örgütsel sosyalleşme süreci, rol alma, yeni işgörenin kimliğinin biçimlenmesi, kurallara ve değerlere uyum sağlaması, örgüte ve amaçlarına yönelik olumlu tutum geliştirmesi, örgüt amacına ve olumlu ilişkilere yönelik davranış geliştirmesi gibi ögeleri kapsamaktadır. Bu nedenle temelde işgöreni seçme ve işe alma ile başlayan örgütsel sosyalleşme, işgörenin görev uzmanlığı sağladığı, yeteneklerini geliştirdiği, işe ilişkin gerekli bilgileri öğrendiği, kısaca deneyim kazandığı ve bu doğrultuda örgütle özdeşleştiği önemli bir süreçtir (Feldman 1980).

Başarılı sosyalleşmenin birey ve örgüt açısından birçok yararı bulunmaktadır. Bu sonuçlarından biri yüksek düzeyde bağl1l1ktır. Örgüt içerisindeki değerlere bağl1lık örgüte yeni giren işgörenlerin örgütü benimsemelerini kolaylaştırır. Başarılı bir örgüt yapısı yeni iş görenin işe ve örgüte uyumlu bir sosyalleşme sürecini zorunlu k1lar. Örgütler yeni üyelere kültürlerini aktarmak için belli bir çaba içine girerler. Çünkü örgütlerin güçlülüğü güçlü örgüt kültürüyle mümkün olur (Nelson ve Quick, 1997).

Örgüte yeni girenler sosyalleşmenin farklı aşamalarında farklı deneyimler yaşamaktadırlar (Young 2003). Bu bağlamda işgören seçim sürecinde en fazla uyum gösterme potansiyeline sahip adayların işe alınması önemli olmaktadır, çünkü uyum potansiyeli yüksek çalışanların işe alınmasıyla birlikte sosyalleşme etkinlikleri için harcanacak zaman ve emek büyük ölçüde azalacaktır (Levine ve Moreland 1999). Buna göre sürekliliği olan ve uzun dönemi kapsayan örgütsel sosyalleşme sürecinde genellikle öngörme, karşılaşma ve değişim olmak üzere üç aşama bulunmaktadır (Chiu 2007).

1- Öngörme Aşaması: Bireyler bir işe girmeden önce örgüt ve yapacakları iş hakkında bilgi edinmek isterler. Ancak iş ve örgüte uyum konusunda belirsizliğe sahip olan birey henüz örgüte ilişkin ögeleri deneyimlemediğinden, bu bilgileri öngörü niteliğindedir. Bu süreçte, belirsizliğe bağlı olarak ve stres düzeyi yüksektir ve işe alındıklarında, örgütün kendilerine ne gibi olanaklar sağlayabileceğine ilişkin birtakım beklentileri vardır (Chiu 2007).

2- Karşılaşma Aşaması: Karşılaşma aşaması işgören yeni bir işe başladığında gelişir. İş görüşmelerinde verilen bilgiler ne kadar gerçekçi olursa olsun yeni bir işe başlayan bireyler için yeni örgüt sürprizler barındırmaktadır. İşe yeni başlayanlar işleri tanımalı, uyum sürecine yönelik eğitim almalı, örgüt kültürünü tanımalıdır (Noe, 2009). Beklentilerin karşılandığı ya da karşılanmadığı, belirsizliklerle ve çatışmalarla karşılaşılan, performansın birey ve örgüt tarafından değerlendirildiği bu aşama hem birey hem de örgüt için kritik önem taşır (Çalık, 2003). 
3- Değişim Aşaması: Bu son aşamada, birey katıldığı örgütün kültürüne ve kendisine verilen rol ve görevlere uzun süreli uyum gösterme çabası içine girmektedir. Değişim aşamasında, örgütün kültürünü benimseyen işgören işini severek yapmakta, örgütün değerlerine, kurallarına, inançlarına uygun tutum ve davranışları sergilemekte, örgütün değerlerini savunarak örgüt üyesi kimliğini kazanmakta, yüksek düzeyde güdülenme ve bağl1lık göstermekte ve bu bağlamda diğer örgüt üyeleri tarafindan benimsenmesi söz konusu olmaktadır (Ardts, Jansen ve Velde, 2001; Garavan ve Claire, 2001; Akt: İplik, 2009).

Eğitim örgütlerinde sosyalleşme süreci, eğitim çalışanlarının okulun etkin bir üyesi olmaları süreci ile başlar. Sosyalleşme eğitim çalışanları ile okul başarısı arasında bir halkadır. Okulda örgütsel sosyalleşme süreci, öğretmen ve yöneticilerin okuldaki rollerini edinmeleri, okul kültürünü benimsemeleri, işe yönelik olumlu tutumun oluşması ve yeni görevsel kimliklerin kazanılması olarak görülmektedir (Kartal, 2007). Öğretmenin sosyalleşmesi, göreve yeni başlayan bir öğretmenin okuldaki öğretmenler, yöneticiler, veli ve öğrencilerle etkileşimleri sonucu geliştirdikleri her türlü değişimi ifade etmektedir (Güçlü, 2004). Örgütsel sosyalleşme öğretmenin okulla özdeşleşmesi, ortak hedef ve değerleri paylaşması ve okul adına çaba sarf etmek için istekli olması anlamına gelir. Eğer öğretmenlerin örgütsel sosyalleşme süreci başarılı olursa öğretmenlerin edimi artacak, yüksek iş doyumu ile düşük seviyede stres belirtileri göstereceklerdir (Çalık, 2006).

Örgütsel sosyalleşme öğretmenlerin meslek yasamı boyunca devam eden bir süreçtir. Öğretmenin hizmet öncesi eğitimi, okuldaki deneyim süreçleri ve katıldıkları tüm hizmet içi eğitimler onların gerçek anlamda bir eğitimci olmaları içindir. (Kartal, 2003). Öğretmenlerin sosyalleşmesine ilişkin yapılan araştırmaların odağında; Öğretmenlerin sosyalleşme sürecinin göreve başladıkları ilk yıllarda meydana geldiği varsayımıyla aday öğretmenler ve göreve yeni başlayan öğretmenler oluşturmaktadır (Blase, 1986). Ancak yapılan araştırmalar, kıdemli öğretmenlerin de örgüt içerisindeki rol değişikliklerinin veya yeni eğitimsel çevrelere girmelerinin onlarda değişime sebep olduğunu göstermesinden dolayı, öğretmenlerin sosyalleşmelerinin mesleki kariyerleri boyunca devam etmesi gerekmektedir (StatonSpicer ve Darling, 1986). Bu durumda sosyalleşme belli bir sürede tamamlanan bir durum değil, okul kültür ve değerlerinin, eski, yeni öğretmen ayırımı yapılmadan bütün öğretmenlere aktarılması gereken bir süreçtir (Zoba, 2000: 44).

Öğretmenin sosyalleşmesi; öğretmenin okulun temel değer, norm, felsefe ve misyonunu öğrenmesidir. Okula yeni gelen öğretmen, okulun planlama, politika, prosedür, eğitim ilkeleri, uygulama ve değerleri doğrultusunda değişir. Öğretmenlerin sosyalleşmesi seçme sisteminden geçmeleriyle başlar, daha sonra okulda deneyim kazanarak değişime uğrar. Bu süreçte başta yöneticilerin yaklaşımı olmak üzere okuldaki destekleyici çabalar, bu süreci olumlu etkiler ve hızlandırır. Okullardaki yapısal durum, karmaşık iklim ve teftiş süreçleri öğretmenin sosyalleşmesini doğrudan etkilemektedir. Yeni öğretmenler nadiren okulun politika, prosedür, planlama eğitim ilkelerine hemen uyum sağlamaktadır. Sosyalleşme süreci örgüte girişte mesleğe başlayınca sona eren bir süreç değildir öğretmenin meslek hayatı boyunca devam ettiği bir süreçtir (Kartal, 2003).

\section{Örgütsel Vatandaşlık ve Örgütsel Sosyalleşme ilişkisi}

Örgütsel sosyalleşme araştırmaları, örgütsel sosyalleşme ve örgütsel vatandaşlık davranışları arasında pozitif bir ilişki olduğunu ortaya çıkarmıştır (Feldman, 1981). Örgütsel bakış açısı göz önüne alındığında, çalışanların uyumlu çalışması uzun vadeli iş hayatı için önemlidir. Çevredeki hızlı değişim hem işverenler hem de çalışanlar üzerinde kültürel ve yönetsel değişikliklere sebep olmaktadır. Böylece, yeni örgüt çalışanlarının, iş beklentilerini ölçmek için doğru araçlara ve bilgilere ihtiyaç duyulmaktadır (Watchfogel, 2009).

Örgüt çalışanlarının örgütsel sosyalleşme ve örgütsel vatandaşl1k sürecindeki uyum süreci, çalışanların inançları ve değerleri ile kuruluşun kültürü, normları ve değerleri arasında oluşan bir kişi-çevre uyumu ile ortaya çıkmaktadır. Okullarda öğretmenlerin sosyalleşmeleri, onların rol ve davranışlarını, okulun değerlerini, kurallarını, tarihini, politikalarını, vizyonunu, misyonu, kültürünü, öğrenmesi, okuldaki yöneticiler, öğretmenler ve diğer çalışanlarla iyi ilişkiler kurarak kendilerini okulun bir üyesi olarak görmeleri ile sonuçlanır (Killeavy ve Moloney, 2010). Öğretmenlerin okullardaki örgütsel yapıya uyumları da onları çevreleyen çevre etkenlerine karşı uyumlarıyla orantılıdır.

Örgütsel sosyalleşme ve örgütsel vatandaşlık kavramları günümüze değin üzerinde pek çok araştırma yapılmış kavramlar olsa da çalışanların örgütsel sosyalleşme düzeylerinin örgütsel vatandaşlık 
düzeylerine etkisi ve aralarındaki ilişki konusunda fazla sayıda araştırmaya rastlanmamıştır. Bu iki kavramın eğitim örgütlerinde bir biriyle ilişkisinin önemi, bu konuda bir araştırma yapılmasını gerekli kılmıştır. Bu çalışmanın amacı; öğretmenlerin örgütsel sosyalleşme düzeylerinin, örgütsel vatandaşlık düzeylerinin anlamlı bir yordayıcısı olup olmadığını incelemektir.

\section{Yöntem}

$\mathrm{Bu}$ araştırma, yordalayıcı ilişkisel tarama modelinde desenlenmiş nicel bir çalışmadır. Yordalayıcı ilişkisel tarama modeli, iki ya da daha çok sayıdaki değişken arasındaki birlikte değişimin varlı̆̆ını ve/veya derecesini belirlemeyi amaçlayan araştırma modeli olarak tanımlanmaktadır. İlişkisel tarama modellerinde, ilişkisel çözümleme; korelasyon türü ilişki ve karşılaştırma yolu ile yapılabilmektedir. Karşılaştırma türü ilişkisel tarama modelinde, en az iki değişken bulunur ve bunlardan birine (bağımsız değişkene) göre gruplar oluşturularak, öteki değişkene (bağımlı değişkene) göre aralarında bir değişme olup olmadığ incelenir (Can, 2013; Karasar, 2005).

\section{Evren ve Örneklem}

Araştırmanın evrenini, 2015-2016 eğitim yılında İstanbul İli Esenyurt İlçesinde bulunan kamuya bağlı liselerde görevli öğretmenler oluşturmaktadır. Araştırmada evrenin tamamına ulaşılmaya çalışılmıştır. Araştırmada, İstanbul İli Esenyurt İlçesi sınırları içerisinde yer alan 14 lisede görev yapan 600 öğretmene veri toplama aracı dağıtılmıştır. Ölçek öğretmen ve yöneticilere bireysel olarak uygulanmıştır. Belli bir süreden sonra \% 86,9'u (n:522) geri alınabilmiştir. Okullardan geri alınan 522 ölçeğin 42'si eksik ve çift şı cevaplama nedeniyle değerlendirmeye alınmamış, 480 öğretmen araştırmanın örneklemini oluşturmuştur.

Araştırmaya katılan öğretmenlerin 274'ü $(\% 57,1)$ kadın, 206`s1 $(\% 42,9)$ erkek öğretmenler oluşturmaktadır. Öğretmenlerin 38'i $(\% 7,9)$ yönetici, 442 'si $(\% 92,1)$ öğretmenlerden oluşturmaktadır. Araştırmaya katılan öğretmenlerin 142'si $(\% 29,6)$ 24-29 yaş aralı̆̆ında, 141'i $(\% 29,4)$ 30-35 yaş aralığında, 120 'si (\%25,0) 36-41 yaş aralığında, 77'si (\%16) 42 yaş ve üstündedir. Öğretmenlerin 370'i lisans (\%77,1), 110'u (\%22,9)'u lisansüstü düzeyde öğrenim görmüştür. Öğretmenlerin 327'si (\%68,1) evli, 153'ü $(\% 31,9)$ ise bekardır. Araştırmaya katılan öğretmenlerin 229'u (\%43.5) 0-5 yıl arası kıdeme, 96's1 (\%20,0) 6-10 y1l arası kıdeme, 80'i (\%16,7) 11-15 yıl arası kıdeme, 95'i (\%19,8) 16 y1l ve üzeri k1deme sahiptir.

\section{Verilerin Toplanması}

Araştırmanın verileri Örgütsel Sosyalleşme Ölçeği ve Örgütsel Vatandaşlık Davranışı Ölçeği ile toplanmıştır. Ölçeklerle ilgili ayrıntılı bilgiye aşağıda yer verilmiştir.

Öğretmenlerin örgütsel sosyalleşme düzeylerini belirlemek için Erdoğan (2012) tarafından geliştirilen, 24 sorudan oluşan, "Örgütsel Sosyalleşme Ölçeği” kullanılmıştır. Ölçek 5 boyuttan (mesleki yeterlilik, örgüt politikası, örgüt dili ve tarihi, kişilerarası ilişkiler, amaç ve değerler) oluşmaktadır. Bunlar, mesleki yeterlilik, örgüt politikası, örgüt dili ve tarihi, kişiler arası ilişkiler, amaç ve değerler boyutudur. Ölçeğin mesleki yeterlilik boyutu için Cronbach alpha değeri .90, kişilerarası ilişkiler boyutu için Cronbach alpha değeri .90, örgüt dili ve tarihi boyutu için Cronbach alpha değeri .88, örgüt politikası boyutu için Cronbach alpha değeri .87, amaç ve değerler boyutu için Cronbach alpha değeri .93 bulunmuştur. Ölçeğin toplam maddeleri için Cronbach alpha değeri .95 olarak belirlenmiştir. Örgütsel sosyalleşme ölçeğinin boyutlarının iç uyum güvenirliklerinin yüksek derecede güvenilir olduğu görülmektedir.

Öğretmenlerin örgütsel vatandaşlık davranışlarını belirleyebilmek için Podsakoff, MacKenzie, Moorman ve Fetter (1990) ve Moorman (1991) tarafindan geliştirilen ve Polat (2007) tarafindan Türkçeye uyarlanan "Örgütsel Vatandaşlık Davranışı Ölçeği" kullanılmıştır. Ölçek 4 boyuttan ve 20 maddeden oluşmaktadır. Bu alt boyutlar, yardımlaşma, centilmenlik, vicdanlılık ve sivil erdemdir. Ölçek beşli Likert tipindedir. Polat (2007) tarafindan yapıları analizde ölçeğin Cronbach's Alpha katsayısı .89 , yardımlaşma boyutunda .86 ; centilmenlik boyutunda .81 ; vicdanlılık boyutunda .88 ve sivil erdem boyutunda ise .82 olarak bulunmuştur.

\section{Verilerin Analizi}

Ölçeklerden elde edilen veriler kodlanarak sosyal bilimler için geliştirilmiş olan bir program yardımıyla çözümlenmiştir. Ölçeğin birinci bölümüyle ilgili verilere ilişkin frekans ve yüzde dağılımları alınmış, 
araştırmaya katılanların örgütsel sosyalleşme ve örgütsel vatandaşlık davranışı düzeylerinin belirlenmesine yönelik olarak aritmetik ortalama ve standart sapma puanları hesaplanmıştır. Örneklem grubunu oluşturan öğretmenlerin ve yöneticilerin örgütsel sosyalleşme ve örgütsel vatandaşl1k davranışları arasında anlamlı bir ilişki bulunup bulunmadığını belirlemek amacıyla Pearson korelasyon analizi, örgütsel sosyalleşmenin örgütsel vatandaşlık davranışını yordama düzeyini belirlemek amacıyla basit doğrusal regresyon analizi yapılmıştır. Görüşler arasında anlamlı bir farklılık olup olmadığı $\alpha=0.05$ anlaml11ık düzeyinde test edilmiştir.

\section{Bulgular ve Yorum}

Bu bölümde araştırma probleminin çözümüne ilişkin, toplanan verilerin analizlerine ait bulgular ve yorumlar alt problemler doğrultusunda yer almaktadır.

Birinci alt probleme ilişkin bulgular

Tablo 1: Öğretmenlerin Örgütsel Sosyalleşme Düzeylerine İlişkin Betimsel Analiz Sonuçları

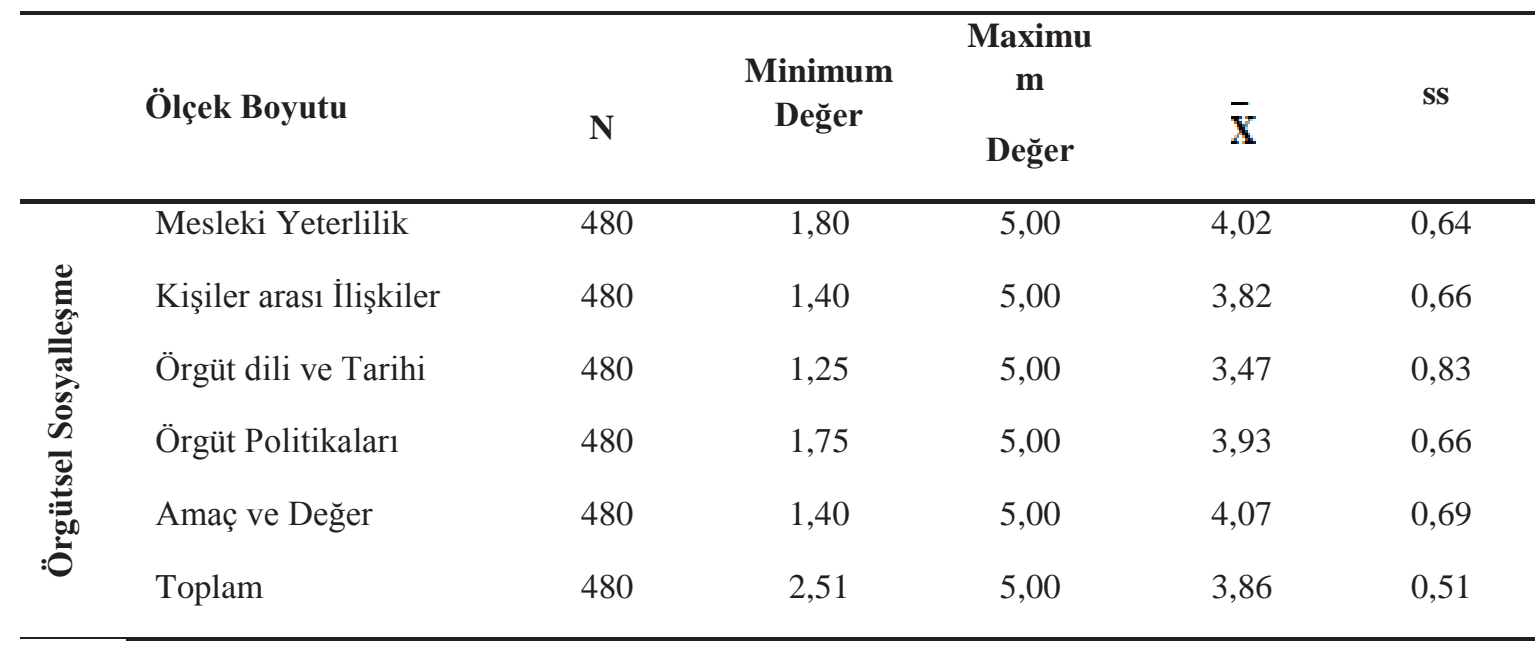

Tablo 4-1 incelendiğinde lise öğretmenlerinin örgütsel sosyalleşme düzeyleri puan ortalamalanı görülmektedir. Lise yönetici ve öğretmenlerinin mesleki yeterlilik puan ortalamalar $\overline{\mathbf{x}}_{-}=4.02$ yüksek düzeyde, lise yönetici ve öğretmenlerinin kişilerarası ilişkiler puan ortalamaları $\overline{\mathbf{X}}_{=} 3.82$ yüksek düzeyde, lise yönetici ve öğretmenlerinin örgüt dili ve tarihi puan ortalamaları $\overline{\mathbf{X}}=3.47$ yüksek

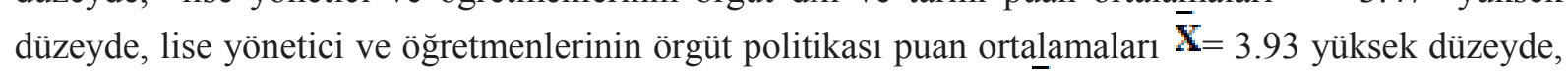
lise yönetici ve öğretmenlerinin amaç ve değerler puan ortalamaları $\overline{\mathbf{X}}=4.07$ yüksek düzeydedir. Birinci alt problemin bulgularına göre lise yönetici ve öğretmenlerinin örgütsel sosyalleşme düzeyleri genel puan ortalamaları $\left(\overline{\mathbf{X}}_{=3,86)}\right.$ iken en yüksek algıladıkları boyut amaç ve değer boyutu $\left(\overline{\mathbf{X}}_{=4.02}\right)$, en düşük algıladıkları boyut örgüt dili ve tarihi boyutu ( $\overline{\mathbf{X}}=3.47)$ ' dur.

Tablo 2: Öğretmenlerin Örgütsel Vatandaşlık Düzeylerine İlişkin Betimsel Analiz Sonuçları

\begin{tabular}{|c|c|c|c|c|c|c|}
\hline & Ölçek Boyutu & $\mathbf{N}$ & $\begin{array}{c}\text { Minimum } \\
\text { Değer }\end{array}$ & $\begin{array}{c}\text { Maximum } \\
\text { Değer }\end{array}$ & $\mathrm{x}$ & ss \\
\hline \multirow{5}{*}{ 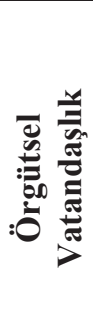 } & Centilmenlik & 480 & 1,00 & 5,00 & 4,13 & 0,91 \\
\hline & Vicdanlı11k & 480 & 1,00 & 5,00 & 4,26 & 0,63 \\
\hline & Sivil Erdem & 480 & 2,00 & 5,00 & 3,89 & 0,64 \\
\hline & Yardımlaşma & 480 & 2,13 & 5,00 & 4,13 & 0,48 \\
\hline & Toplam & 480 & 2,72 & 5,00 & 4,10 & 0,47 \\
\hline
\end{tabular}


Tablo 4-2 incelendiğinde lise yönetici ve öğretmenlerinin örgütsel vatandaşlık Xüzeyleri puan ortalamaları görülmektedir. Lise öğretmenlerinin centilmenlik puan $\bar{X}^{\text {rtalamaları }}=4.13$ yüksek düzeyde, lise yönetici ve öğretmenlerinin vicdanlılık puan or $\overline{\mathbf{X}}$ lamaları $=4,26$ çok yüksek düzeyde, lise yönetici ve ögretmenlerinin sivil erdem puan o $\overline{\mathbf{X}}$ alamaları $=3.89$ yüksek düzeyde, lise yönetici ve öğretmenlerinin yardımlaşma puan ortalamaları $=4,13$ yüksek düzeydedir. Birinci alt problemin bxłgularına göre lise yönetici ve öğretmenlerinin örȳütsel vatandaşlık düzeyleri genel puan ortalamaları $\overline{\mathbf{X}}=4,10)$ iken en yüksek algıladıkları vicdanlılık ( $=4.26)$, en düşük algıladıkları sivil erdem boyutu ( $=3.89$ )'dur.

\section{Öğretmenlerin Örgütsel Sosyalleşme Düzeylerinin Örgütsel Vatandaşlık Düzeyleri Arasındaki İlişki}

Araştırmanın üçüncü alt problemi olan öğretmenlerin örgütsel sosyalleşme düzeyleri ve örgütsel vatandaşlık düzeylerine yönelik görüşleri arasında anlamlı ilişki olup olmadığını tespit etmek için yapılan korelasyon analizi sonucu elde edilen veriler Tablo 4-17'de gösterilmiş̧ir.

Tablo 4: Örgütsel Sosyalizasyon ve Örgütsel Vatandaşlık Davranışı Arasındaki İlişkiye Yönelik Korelasyon Analizi Sonuçları

\begin{tabular}{|c|c|c|c|c|c|c|c|c|c|c|c|c|c|}
\hline & & & 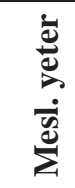 & 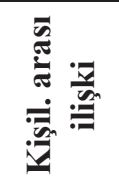 & 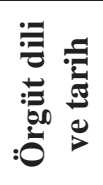 & 童 & : & 离 & Uี & 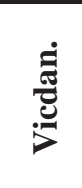 & 疍 & $\dot{E}$ & 节 \\
\hline \multirow{10}{*}{ 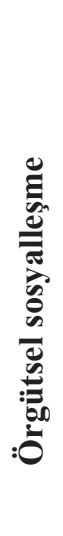 } & $\begin{array}{c}\text { Mesleki } \\
\text { yeter }\end{array}$ & $\begin{array}{l}\mathrm{r} \\
\mathrm{p}\end{array}$ & 1 & & & & & & & & & & \\
\hline & \multirow{2}{*}{$\begin{array}{c}\text { Kişiler } \\
\text { arası ilişsi }\end{array}$} & $r$ & ,36 & 1 & & & & & & & & & \\
\hline & & $\mathrm{p}$ & ,00 & & & & & & & & & & \\
\hline & \multirow{2}{*}{$\begin{array}{l}\text { Örgüt dili } \\
\text { ve tarih }\end{array}$} & $r$ & ,39 & ,42 & 1 & & & & & & & & \\
\hline & & $\mathrm{p}$ & ,00 &, 00 & & & & & & & & & \\
\hline & \multirow{2}{*}{$\begin{array}{c}\text { Örgüt } \\
\text { politika }\end{array}$} & $\mathrm{r}$ &, 51 & ,48 & ,55 & 1 & & & & & & & \\
\hline & & $\mathrm{p}$ &, 00 &, 00 & ,00 & & & & & & & & \\
\hline & \multirow{2}{*}{$\begin{array}{l}\text { Amaç ve } \\
\text { değer }\end{array}$} & $\mathrm{r}$ & ,33 & ,44 & ,31 & ,47 & 1 & & & & & & \\
\hline & & $\mathrm{p}$ &, 00 &, 00 & ,00 & ,00 & & & & & & & \\
\hline & \multirow[t]{2}{*}{ Toplam } & $\mathrm{r}$ & ,69 & ,72 & ,75 & ,81 & 69 & 1 & & & & & \\
\hline \multirow{12}{*}{ 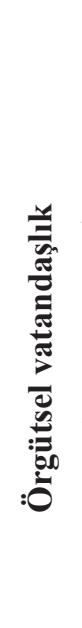 } & & $\begin{array}{l}\mathrm{D} \\
\mathrm{N}\end{array}$ & $\begin{array}{l}.00 \\
480\end{array}$ & $\begin{array}{l}.00 \\
480\end{array}$ & $\begin{array}{l}.00 \\
480\end{array}$ & $\begin{array}{l}.00 \\
480\end{array}$ & $\begin{array}{l}.00 \\
480\end{array}$ & & & & & & \\
\hline & \multirow{2}{*}{ Centilmenlik } & $\mathrm{r}$ & ,13 & ,08 & - & ,17 & ,22 & ,14 & 1 & & & & \\
\hline & & $\mathrm{p}$ & ,00 & ,07 & ,39 & 00 & ,00 & ,00 & & & & & \\
\hline & \multirow{2}{*}{ Vicdanlılık } & $r$ & ,26 & ,22 & ,11 & ,22 & ,24 & ,28 & ,27 & 1 & & & \\
\hline & & $\mathrm{p}$ &, 00 &, 00 & 01 & 00 & ,00 & 00 & ,00 & & & & \\
\hline & \multirow{2}{*}{$\begin{array}{c}\text { Sivil } \\
\text { erdem }\end{array}$} & $r$ & ,25 & ,41 & ,35 & ,34 & ,39 & ,47 & ,13 & ,35 & 1 & & \\
\hline & & $\mathrm{p}$ &, 00 &, 00 & ,00 & 00 & 00 & ,00 & ,00 & ,00 & & & \\
\hline & \multirow{3}{*}{ Yardımlaşma } & $r$ & ,34 & ,37 & ,26 & ,42 & ,34 & ,47 & ,33 & ,42 & ,50 & 1 & \\
\hline & & $\mathrm{p}$ & ,00 &, 00 & 00 & 00 & 00 & ,00 & ,00 & 00 & 00 & & \\
\hline & & $\mathrm{r}$ & ,33 & ,35 & ,20 & ,39 & ,41 & ,45 & ,71 & ,70 & ,65 & ,73 & 1 \\
\hline & \multirow[t]{2}{*}{ Toplam } & $\mathrm{p}$ &, 00 &, 00 & 00 & 00 & ,00 &, 00 & ,00 & ,00 & 00 & ,00 & \\
\hline & & $\mathrm{N}$ & 480 & 480 & 480 & 480 & 480 & 480 & 480 & 480 & 480 & 480 & 480 \\
\hline
\end{tabular}

$* * \mathrm{p}<.01$

Tablo 4-17 incelendiğinde, öğretmenlerin örgütsel sosyalleşme ve örgütsel vatandaşl1k düzeyleri arasında pozitif yönde anlamlı ilişkiler bulunmuştur. Öğretmenlerin örgütsel sosyalleşme ve örgütsel 
vatandaşlık düzeylerine ilişkin görüşlerine yönelik toplamlar incelendiğinde elde edilen bulgular şunlardır:

Öğretmenlerin sosyalleşmeleri ile mesleki yeterlik $(r=, 693, p<.01)$, kişilerarası ilişkiler $(r=729, p<.01)$, örgüt tarihi ve dili $(\mathrm{r}=, 757, \mathrm{p}<.01)$, örgüt politikası $(\mathrm{r}=, 818, \mathrm{p}<.01)$, örgütsel amaç ve değerlere uyum $(\mathrm{r}=, 690, \mathrm{p}<.01)$ boyutları arasında yüksek düzeyde pozitif ilişki olduğu görülmektedir. Öğretmenlerin örgütsel vatandaşlıkları ile centilmenlik $(r=, 711, \mathrm{p}<.01)$, vicdanlıl1k $(r=, 701, \mathrm{p}<.01)$, sivil erdem $(\mathrm{r}=, 657$, $\mathrm{p}<.01)$, yardımlaşma $(\mathrm{r}=, 739, \mathrm{p}<.01)$ boyutları arasında yüksek düzeyde pozitif ilişki olduğu görülmektedir. Öğretmenlerin sosyalleşme düzeyi ile mesleki yeterlikleri, kişiler arası ilişkileri, örgüt tarihi ve dili, örgüt politikasını ile amaç ve değer arasında yüksek düzeyde ilişki olduğu görülmektedir. Öğretmenlerin vatandaşlık düzeyleri arttıkça centilmenlik, vicdanlılık, sivil erdem ve yardımlaşmaya ilişkin olumlu görüşleri artmaktadır.

Öğretmenlerin centilmenlik düzeyleri ile mesleki yeterlik $(\mathrm{r}=, 133, \mathrm{p}<.01)$, örgüt politikası $(\mathrm{r}=, 179$, $\mathrm{p}<.01)$ boyutları, örgütsel amaç ve değerlere uyum $(\mathrm{r}=, 226, \mathrm{p}<.01)$ boyutları; toplam örgütsel sosyalleşme düzeyi $(\mathrm{r}=, 149, \mathrm{p}<.01)$ arasında pozitif ilişki olduğu görülmektedir. Centilmenlik boyutunda kişiler arası ilişki ve örgüt dili ve tarihi arasında anlamlı bir ilişki araştırma sonucunda görülmemiştir. $\mathrm{Bu}$ durumda okulun amaçlarını kendi amaçları ile benzer gören öğretmenler için sosyalleşme sürecinin öğretmenlerin örgütsel vatandaşlı̆̆ın centilmenlik boyutunda davranışlarının oluşmasında etkili olduğu söylenebilir. Öğretmenlerin vicdanlılıkları ile mesleki yeterlik $(\mathrm{r}=, 261$, $\mathrm{p}<.01)$, kişilerarası ilişkiler ( $\mathrm{r}=, 229, \mathrm{p}<.01)$, örgüt tarihi ve dili $(\mathrm{r}=, 110, \mathrm{p}<.01)$, örgüt politikası $(\mathrm{r}=, 228$, $\mathrm{p}<.01)$,örgütsel amaç ve değerlere uyum $(\mathrm{r}=, 247, \mathrm{p}<.01)$ boyutları; toplam örgütsel sosyalleşme düzeyi $(\mathrm{r}=, 284, \mathrm{p}<.01)$ arasında orta düzeyde pozitif ilişki olduğu görülmektedir. Vicdanlılık boyutundaki örgütsel vatandaşlık düzeyinin örgütsel sosyalleşmenin en fazla mesleki yeterlilik boyutu ile ilişkili olduğu görülmektedir.

Öğretmenlerin örgütsel vatandaşlığın sivil erdem boyutuna ilişkin görüşleri ile mesleki yeterlik $(r=, 253$, $\mathrm{p}<.01)$, kişilerarası ilişkiler ( $\mathrm{r}=, 411, \mathrm{p}<.01)$, örgüt tarihi ve dili $(\mathrm{r}=, 352, \mathrm{p}<.01)$, örgüt politikası $(\mathrm{r}=, 344$, $\mathrm{p}<.01)$, örgütsel amaç ve değerlere uyum düzeyi $(\mathrm{r}=, 394, \mathrm{p}<.01)$ boyutları; toplam örgütsel sosyalleşme düzeyi $(\mathrm{r}=, 394, \mathrm{p}<.01)$ arasında orta düzeyde pozitif ilişki olduğu görülmektedir. Buradan hareketle öğretmenlerin örgüt içerisindeki aidiyet duygusunun artması ile öğretmenlerdeki örgüt kültürünü kabullenme ve sosyalleşme yönünde olumlu bir ilişki olduğu görülmektedir. Öğretmenlerin örgütsel vatandaşlı̆̆ın yardımlaşma boyutuna ilişkin görüşleri ile mesleki yeterlik $(\mathrm{r}=, 348, \mathrm{p}<.01)$, kişilerarası ilişkiler ( $\mathrm{r}=, 372, \mathrm{p}<.01)$, örgüt tarihi ve dili $(\mathrm{r}=, 266, \mathrm{p}<.01)$, örgüt politikas1 $(\mathrm{r}=, 426, \mathrm{p}<.01)$, örgütsel amaç ve değerlere uyum $(r=, 341, p<.01)$ boyutları; toplam örgütsel sosyalleşme düzeyi $(r=, 470, p<.01)$ arasında orta düzeyde pozitif ilişki olduğu görülmektedir. Buradan hareketle öğretmenlerin örgüt içerisindeki yardımlaşma ve diyalog kültürünü benimseme davranışları ile örgütü tanıma ve kişiler arası ilişkiler kurma davranışları arasında doğrusal bir ilişki olduğu söylenebilir.

Ayrıca örgütsel vatandaşlık boyutu en fazla sosyalleşme boyutunda örgüt politikası ve amaç ve değerlere uyum boyutlarından etkilenmektedir. Bu durum bize örgütün varlık amacını benimsemiş örgütün amaç ve değerlerini içselleştirmiş bireylerin örgüt içerisindeki ilişkilerinde daha fedakar olacağını göstermektedir örgüt içerisindeki bu uyum ve aidiyet örgüt içerisindeki bireylerin örgütü koruma ve yaşama faaliyetlerinde kendilerine verilen veya verilmese bile örgüt için hayatiyet arz eden konularda onların vatandaşlık düzeylerini arttırmaktadır.

Sonuç olarak öğretmenlerin örgütsel sosyalleşme düzeyleri ölçeğinin mesleki yeterlik, kişileraras1 ilişkiler, örgüt tarihi ve dili, örgüt politikası, örgütsel amaç ve değerlere uyum düzeyi ile örgütsel vatandaşlık düzeyleri ölçeğinin centilmenlik, vicdanlılık, sivil erdem ve yardımlaşma boyutları arasında orta düzeyde pozitif ilişki olduğu görülmektedir. Bu nedenle öğretmenlerin sosyalleşme düzeyleri arttıkça vatandaşlık düzeylerinin de artacağını ya da sosyalleşme düzeyleri azaldıkça vatandaşlık düzeylerinin azalacağını söylemek mümkündür.

\section{Öğretmenlerin Örgütsel Sosyalleşme Düzeylerinin Örgütsel Vatandaşılı Düzeylerini Yordamasına İlişkin Bulgular}

Araştırmaya katılan öğretmenlerin örgütsel sosyalleşme düzeylerinin ve örgütsel vatandaşl1k düzeylerini yordamasına ilişkin çoklu regresyon analizi sonuçları Tablo 4-18'de verilmiştir. 
Tablo 4-18 incelendiğinde öğretmenlerin sosyalleşme düzeyi ile vatandaşlık düzeyleri arasında pozitif ilişki bulunmaktadır. Sosyalleşme düzeylerinin $(\mathrm{t}=17,435)$ öğretmenlerin vatandaşlık düzeylerinin anlamlı yordayıcıları olduğu anlaşılmaktadır. Sonuç olarak öğretmenlerin örgütsel sosyalleşmenin örgütsel vatandaşlığı yordamasına ilişkin çoklu regresyon analizine göre öğretmenlerin örgütsel sosyalleşme düzeyinin, örgütsel vatandaşlık düzeylerini olumlu yönde ve orta düzeyde yordadığ görülmüştür $(\mathrm{R}=.454, \mathrm{R} 2=.206, \mathrm{p}<.01)$. Örgütsel vatandaşl1k düzeyine ilişkin toplam varyansın \%20'si ögretmenlerin örgütsel sosyalleşme düzeyleriyle açıklanabilmektedir. Diğer bir ifadeyle öğretmenlerin sosyalleşme düzeylerinin artması ile örgütsel vatandaşlık düzeyleri de artmaktadır. Örgütsel sosyalleşmenin öğretmenlerin örgütsel vatandaşlık düzeylerinin anlamlı bir yordayıcısı olduğu anlaşılmaktadır.

Tablo 4: Öğretmenlerin Örgütsel Sosyalleşme Düzeylerine Göre Örgütsel Vatandaşlık Düzeyleri İçin Yapılan Çoklu Regresyon Analizi Tablosu

\begin{tabular}{cccccc}
\hline $\begin{array}{c}\text { Yordalayan } \\
\text { Değişken }\end{array}$ & B & $\begin{array}{c}\text { Standart } \\
\text { Hataв }\end{array}$ & $\boldsymbol{\beta}$ & $\mathbf{t}$ & $\mathbf{P}$ \\
\hline $\begin{array}{c}\text { Regrasyon } \\
\text { katsayısı }\end{array}$ & 2,516 &, 144 & - & 17,435 &, 000 \\
Sosyalleşme &, 412 &, 037 &, 454 & 11,130 &, 000 \\
\hline $\mathrm{R}=, 454$ & $\mathrm{R}^{2}=, 206$ & & & & \\
$\mathrm{~F}(1-478)=123,887$ & $\mathrm{p}=, 000$ & & & &
\end{tabular}

\section{Sonuç, Tartışma ve Öneriler}

Araştırma sonuçlarına göre öğretmenlerin sosyalleşme düzeyleri yüksek olarak bulunmuştur. Öğretmenlerin örgütsel sosyalleşme boyutlarından en yüksek puanı aldıkları amaç ve değer boyutu da yüksek düzede, en düşük puanı aldıkları örgüt dili ve tarihi boyutu da yüksek düzeyde bulunmuştur. Katılımcı öğretmenlerinin sosyalleşme düzeyleri mesleki yeterlilik, amaç ve değer boyutlarında yüksek değerlerde çıkması, öğretmenlerin okullarının amaç ve değerlerini benimsedikleri, meslekleriyle ilgili olarak kendilerini yeterli hissettikleri ve sorumluluklarının farkında oldukları şeklinde yorumlanabilir. Çapar (2007), Ufuk (2012), Kılıçoğlu ve Yılmaz (2014) ve Çobanoğlu ve Öğretir (2015) tarafindan yapılmış araştırma sonuçlarında da ilköğretim okullarında görev yapan öğretmenlerin örgütsel sosyalleşme düzeylerinin yüksek olduğu bulunmuştur ve araştırmanın bu sonucunu destekler niteliktedir. Öğretenlerin örgütsel sosyalleşmelerinin örgütsel ve bireysel olumlu sonuçları göz önünde bulundurulduğunda bu sonuç oldukça sevindiricidir.

Öğretmenlerin örgütsel vatandaşlık davranışı genel puan ortalamalarının yüksek düzeyde olduğu belirlenmiştir. Öğretmenlerin en yüksek puan ortalamasına sahip örgütsel vatandaşlik alt boyutu vicdanlılık boyutudur ve yüksek düzeydedir. En düşük puan aldıkları boyut ise sivil erdem boyutudur ve bu boyut da yüksek düzeydedir. Vicdanlılık davranışının yüksek düzeyde sergilenmesi öğretmenlerin işleriyle ilgili kurallara uygun davranmayı önemsedikleri, kendilerine tanımlanmış sorumlulukların ötesinde bir sorumluluk anlayış ve düşüncesinde oldukları şeklinde yorumlanabilir. Sivil erdem boyutunda elde edilen sonuç en düşük değerli sonuçtur. Ama bu değerde ortalamanın üstündedir ve yüksek olarak yorumlanmıştır. Genel olarak öğretmenlerin örgütsel vatandaşlık davranışları puan ortalamalarının yüksek olduğu söylenebilir. Oğuz (2011), Baş ve Şentürk (2011), Yılmaz (2010) ve Polat ve Celep (2008) tarafından gerçekleştirilen araştırmalarda da, öğretmenlerin örgütsel vatandaşlık davranışlarının yüksek düzeyde olduğu belirlenmiştir ve araştırmanın bu sonucu ile koşutluk göstermektedir.

Öğretmenlerin örgütsel sosyalleşme düzeyleri mesleki yeterlik, kişilerarası ilişkiler, örgüt tarihi ve dili, örgüt politikası, örgütsel amaç ve değerlere uyum düzeyi ile örgütsel vatandaşlık düzeyleri ölçeğinin centilmenlik, vicdanlılık, sivil erdem ve yardımlaşma boyutları arasında orta düzeyde pozitif yönde bir ilişki olduğu belirlenmiştir. Bir başka deyişle, öğretmenlerin sosyalleşme düzeyleri arttıkça örgütsel 
vatandaşlık düzeylerinin de artacağını ya da sosyalleşme düzeyleri azaldıkça vatandaşlık düzeylerinin azalacağııı söylemek mümkündür.

Araştırmada, ayrıca, öğretmenlerin örgütsel sosyalleşme düzeylerinin örgütsel vatandaşlık davranışlarını yordadığı sonucuna ulaşıımıştır. Örgütsel vatandaşlık düzeyine ilişkin toplam varyansın \%20'si öğretmenlerin örgütsel sosyalleşme düzeyleriyle açıklanabilmektedir. Diğer bir ifadeyle öğretmenlerin örgütsel sosyalleşme düzeylerinin artması ile örgütsel vatandaşlık davranışları da artmaktadır. Örgütsel sosyalleşmenin öğretmenlerin örgütsel vatandaşlık düzeylerinin anlamlı yordayıcısı olduğu anlaşılmaktadır. Salavati, Ahmadi, Sheikhesmaeili ve Mirzaei (2011) tarafindan yapılan örgütsel sosyalleşmenin örgütsel vatandaşlık davranışı üzerindeki etkisi adlı çalışmada, yüksek eğitim kurumlarındaki örgütsel sosyalleşme düzeyleri ve örgütsel vatandaşlık davranışları arasındaki anlamlı bir ilişkinin bulunduğu ve örgütsel sosyalleşme düzeyinin örgütsel vatandaşlık davranışını yordadığı bulunmuştur.

Araştırmaya katılan öğretmenlerin örgütsel sosyalleşme düzeyleri yüksek bulunmuştur ancak çok yüksek değildir. Örgütsel sosyalleşme düzeyinin çok yüksek düzeyde gerçekleşmesi için en büyük görev okul yöneticilerine düşmektedir. $\mathrm{Bu}$ amaçla okul yöneticileri, özellikle göreve yeni başlayan öğretmenlerin sosyalleşme düzeylerini artırabilmek için örgüt tarihi ve dilinin yeni öğretmenlere tanıtılması amacıyla okuldan ayrılan veya emekli olan öğretmenlerin de katıldığı tanışma toplantıları veya okul çayları gibi kültürel etkinlikler düzenleyebilirler. Bu sayede geliştirilen informal ilişkiler, toplumsal sosyalleşmenin adımı olan sosyal duyguların paylaşılmasını sağlayabilir.

Öğretmenlerin örgütsel vatandaşl1k davranışı sergilemeleri okullar için sevindirici bir durumdur ve bunun devamlılığı ve artması için okul müdürleri tarafından bu davranışların desteklenmesi gerekmektedir. Bakanlık da bu noktada öğretmenlerin bireysel ve örgütsel gereksinimlerini göz önünde bulundurarak bu durumun sürdürülebilirliğini sağlamak ve daha iyi bir noktaya taşımak için destek verebilir.

Örgütsel vatandaşlık davranışının, örgütsel sosyalleşme ile belli bir oranda yordandığı sonucuna ulaşılmıştır ancak örgütsel vatandaşlığın yordayıcısı olabilecek, örgütsel güven, örgütsel özdeşleşme, örgütsel adalet, örgütsel özdeşleşme gibi diğer değişkenler araştırmacılar tarafından çalışılabilir. Bunun yanında, öğretmenlerin okul içerisinde sosyalleşme düzeylerini arttırmaya yönelik olarak hangi davranış ve etkinliklerin daha etkili olduğunu belirlemeye yönelik nitel araştırmalar yapılabilir.

\section{Kaynakça}

Alizadeh, H., Ranjbar, M., Ziaee, V., Mohsenipour, R., Mehdizadeh, M., Moradinejad, M. H., \& Alimadadi, H. (2017). The Relationship Between Sonographic Findings, and Clinical and Paraclinical Symptoms in Henoch Schonlein Purpura.

Ardts, J., Jansen, P. \& Velde, M.V. (2001). The Breaking in of New Employees: Effectiveness of Socialization Tactics and Personnel Instruments, Journal of Management Development,20 (2): 159-167.

Ay, B. (2007). Öğretmenlerin Öz Yeterlilikleri ve Örgütsel Vatandaşlık Davranışı, (Yayınlanmamış Yüksek Lisans Tezi). Afyon Kocatepe Üniversitesi, SBE, İlköğretim Anabilim Dalı Sınıf Öğretmenliği Bölümü.

Blase, J. (1986). Socialization as humanization: One side of becoming a teacher. Sociology of Education, 59, 100-113.

Bozkurt, F. (2007). Denizcilik sektöründe çalışan gemi adamlarının demografik özellikleri ile örgütsel bağlllık, örgütsel vatandaşlık davranışı ve algllanan örgütsel destek düzeyi arasındaki ilişkiyi incelemeye yönelik bir araştırma. Yayımlanmamış Yüksek Lisans Tezi, Celal Bayar Üniversitesi Sosyal Bilimler Enstitüsü, Manisa.

Can, A. (2013). SPSS ile bilimsel araştırma süresince nicel veri analizi. Ankara: Pegem Akademi Yayıncılık.

Chiu, Ming-Hsin (2007). Making Sense of Organizational Socialization: Exploring Information Seeking Behavior of Newcomer Digital Librarians in Academic Libraries (Basılmamış 
Doktora Tezi). University of Wisconsin-Madison.

Çalık, C. (2006). Örgütsel sosyalleşme sürecinde eğitimin değişen rolü ve önemi. Kastamonu eğitim fakültesi dergisi, 14 (1), 1-10.

Çalık, T. (2003). İş görenlerin Örgüte Uyumu (Örgütsel Sosyalleşme. Türk Eğitim Bilimler Dergisi. 1(2), 163-177.

Çobanoğlu, F. ve Öğretir, M. (2016). İlköğretim Okullarında Görev Yapan Öğretmenlerin Örgütsel Sosyalleşme Düzeyleri, Pegem Ĕ̈itim ve Öğretim Dergisi, 5(2), 149-166.

Demirci, K., Erbaş, A. ve Giderler A. C. (2009). Üniversite Öğrencilerinin stk'lara Katılım Potansiyellerinin Örgütsel Vatandaşlık Davranışı Boyutlarından Sivil Erdem Boyutu Çerçevesinde İncelenmesi. Khazar University Press, 12 (1-2), 752- 767.

Erdoğan, U. (2012). İlköğretim Okullarının Bürokratik Yapıları ile Öğretmenlerin Örgütsel Sosyalleşme Düzeyleri Arasındaki İlişki: Malatya ili örneği (Yayınlanmamış Yüksek Lisans Tezi, İnönü Üniversitesi).

Ergün, M. (1992). Egitim ve toplum, Ankara: Ocak Yayınları.

Feldman, D.C. (1980). A Socialization Process that Help New Recruits Succeed. İçinde, J.R. Hackman, E.E. Lawler, L.W.

Feldman, D. C. (1981). The multiple socialization of organization members. Academy of Management Review, 6 (2), 309-318.

Güçlü, N. (2004). Öğretmenlik mesleğine başlarken yeni öğretmenlerin örgütsel sosyalleşmeleri”, İlk günden başöğretmenliğe, (Ed. Erçetin, Ş.) 17 - 39. Ankara: Asil Dağıtım.

Güney, S. (2000). Yönetim ve Organizasyon El Kitabı. Yayın No: 27, Ankara: Nobel Yayınları.

Gürbüz, S. (2006). “Örgütsel Vatandaşlık Davranışı İle Duygusal Bağlılık Arasındaki İlişkilerin Belirlenmesine Yönelik Bir Araştırma”, Ekonomik ve Sosyal Araştırmalar Dergisi, 3(2), 48-75.

Gürel, E. B. B. (2012). “İş Girişimcilik: Bir Literatür Tarması”, Gümüşhane Üniversitesi, Sosyal Bilimler Elektronik Dergisi.6, 57-73

Karaman, A. ve Aylan, S. (2012), "Örgütsel Vatandaşl1k”, Kahramanmaraş Sütçü İmam Üniversitesi İ.̇.B.F. Dergisi, 2/1, 35-48.

Kartal, S. (2003). "İlköğretim Okulu Yönetici Ve Öğretmenlerinin Örgütsel Sosyalleşme Düzeyleri” Doktora Tezi, Ankara Üniversitesi, Türkiye.

Kartal, S. (2007). Eğitimde Örgütsel Sosyalleşme. Ankara: Maya Akademi Yayınları.

Kılıçoğlu, G., \& Yılmaz, D. (2014). İlköğretim Okulu Öğretmenlerinin Örgütsel Sosyalleşmeleri Üzerine Yordamsal Bir Analiz. İlköğretim Online, 12(4), 1041-1055.

Killeavy, M. \& Moloney, A. (2010). Reflection in a Social Space: Can Blogging Support Reflective Practice for Beginning Teachers? Teaching and Teacher Education, 26(4), 1070-1076.

Levine J.M. ve Moreland, R.L. (1999). Konowledge Transmission in Work Groups: Helping Newcomers to Succeed.NJ: Mahwah.

Nelson, D. L. ve Quick, J. C. (1997). Organizational Behavior: Foundations, Realities and Challenges. New York: West Publishing Company.

Noe, R. A. (2009). İnsan Kaynaklarının Eğitimi ve Geliştirilmesi. Canan Çetin (çev.). İstanbul: Beta.

Oğuz, E. (2014). Öğretmenlerin Örgütsel Vatandaşlık Davranışları ile Yöneticilerin Liderlik Stilleri Arasındaki İlişki. Kuram ve Uygulamada Ĕ̈itim Yönetimi, 3(3), 377-403.

Organ, D. W. (1977). A Reappraisal and Reinterpretation of The Satisfaction-CausesPerformance Hypothesis. Academy of management Review, 2(1), 46-53.

Organ, D. W. (1990). The Motivational Basis of Organizational Citizenship Behavior. Research in Organizational Behavioral, 43-72.

Özdevecioğlu, M. (2003). “Örgütsel Vatandaşlık Davranışı İle Üniversite Öğrencilerinin Bazı 
Demografik Özellikleri ve Akademik Başarıları Arasındaki İlişkilerin Belirlenmesine Yönelik Bir Araştırma”, Erciyes Üniversitesi İktisadi ve İdari Bilimler Dergisi, Sayı:20, 117-135.

Özkalp, E. (2005), Sosyolojiye Giriş, Ekin Yayınları, Bursa.

Podsakoff P. M., MacKenzie S. B. ve Hui, C. (1993). Organizational Citizenship Behaviors as Determinants of Managerial Evaluations of Employee Performance: A Review and Suggestions For Future Research. Research in Personnel and Human Resources Management, ed. G. R. Ferris, K. M. Rowland. Greenwich: Jai Press, 7.

Podsakoff, P. M. ve MacKenzie, S. B. (1997). Impact Of Organizational Citizenship Behavior on Organizational Performance: A Review and Suggestion For Future Research. Human Performance, 10(2), 133-151.

Podsakoff, P. M., MacKenzie, S. B., Paine, J. B. ve Bachrach, D. G. (2000). Organizational citizenship behaviors: A critical review of the theoretical and empirical literature and suggestions for future research. Journal of management, 26(3), 513-563.

Polat, S. Ve Celep, C. (2008). Ortaöğretim Öğretmenlerinin Örgütsel Adalet, Örgütsel Güven, Örgütsel Vatandaşlık Davranışlarına İlişkin Algıları. Kuram ve Uygulamada Egitim Yönetimi Dergisi, 14(2), 307-331.

Terzi, A.R. (2011). Denetim Odağı ve Örgütsel Vatandaşlık Davranışı İlişkisisi: Üniversite Öğrencileri Üzerinde Bir Araştırma, Eğitim ve Bilim, Cilt:36, Sayı:162.

Titrek, O., Bayrakçı, M. ve Zafer, D. (2009). Öğretmenlerin Örgütsel Vatandaşlık Davranışlarına İliş̧kin Görüşleri. Akademik Bakış, 17, 88-107.

Sezgin, F. (2005). Örgütsel Vatandaşlık Davranışları: Kavramsal Bir Çözümleme ve Okul Açısından Bazı Çıkarımlar, Gazi Üniversitesi Gazi Eğitim Fakültesi Dergisi, 25(1), 313339.

Smith, C. A., Organ, D. W. ve Near, J. P. (1983). Organizational citizenship behavior: Its nature and antecedents. Journal of applied psychology, 68(4), 653.

Staton-Spicer, A. Q. ve Darling, A. L. (1986). Communication in the socialization of preservice teachers. Communication Education, 35, 215-230.

Wachtfogel, M. (2009). Organizational Socialization, Person-Environment Fit and Commitment of Recent College Graduates. PhD Thesis. New York University Steinhardt School of Culture, Education, and Human Development.

Yılmaz, K. (2010). Kamu Ortaöğretim Okulu Öğretmenlerinin Örgütsel Vatandaşlık Davranışları ile İlgili Görüşleri. Ondokuz Mayıs Üniversitesi Eğitim Fakültesi Dergisi, 29(1), 1-16.

Young, C.A. (2003). Organizational Socialization: Messages, Meanings and Making Sense. İçinde, Salih Kusluvan (Editörler). Managing Employee Attitudes and Behaviors in the Tourism and Hospitality Industry. USA: Nova Science Publishers, Inc. 289-308.

Zoba, A. (2000). “ İlköğretim okullarında var olan örgütsel değerlerle öğretmenlerin sosyalleşmesi arasındaki ilişki” Yayımlanmamış Yüksek Lisans Tezi, Ankara Üniversitesi Sosyal Bilimler Enstitüsü, Ankara. 